\title{
Specifics of Communication in Lithuanian Voting Campaigns, 2012-2016
}

\author{
Liudas Mažylis ${ }^{1}$ \\ Ingrida Unikaitè-Jakuntavičien $\dot{e}^{2}$ \\ Romualdas Povilaitis ${ }^{3}$
}

\begin{abstract}
The rapid growth of the numbers of unaffiliated voters and the internet users caused politicians' interest in these audiences and the start of their activities in these communication channels by establishing more personalized relationships with voters. This paper aims to analyze the communication of main parties and their candidates in social media channel "Facebook" and in popular Lithuanian internet news media portals, such as delfi.lt, Irytas.It and others before the Parliamentary elections in 2012 and the forthcoming 2016 Parliamentary elections. Both quantitative and qualitative aspects of campaign coverage in the media portals and Facebook are analysed. The paper addresses the following questions: How important are factors such as new party emergence, parallel referendum campaign, and activity of using social media for the final result of elections? How active were the politicians in the Facebook? What content dominated their profiles? How much personalized were their messages? What strategies were used for communication? Did the politicians aim at mobilizing or at persuasion the voters? Involvement of citizens, voters' turnout and political results are linked with campaign arguments and the value normative environment. We conclude by providing the discussion on the noticed tendencies and possible improvements in the communication of candidates for the future.
\end{abstract}

Key words: elections, media, communication, Lithuania, personalization

\section{INTRODUCTION}

The rapid growth of numbers of unaffiliated voters and the internet users caused politicians' interest in these audiences and the start of their activities in these communication channels by establishing more personalized relationships with voters. Lithuania is not an exception. The last four years we may notice active involvement of politicians' presentation of their opinions on various

\footnotetext{
${ }^{1}$ Dr. Liudas Mažylis, Faculty of Political Sciences and Diplomacy, Vytautas Magnus University, e-mail: liudas.mazylis@vdu.lt.

${ }^{2}$ Dr. Ingrida Unikaite-Jakuntavičiene, Faculty of Political Sciences and Diplomacy, Vytautas Magnus University, e-mail: ingrida.unikaite-jakuntaviciene@vdu.lt.

${ }^{3}$ Dr. Romualdas Povilaitis, Vytautas Magnus University, Kaunas, Lithuania, e-mail: romualdas. povilaitis@gmail.com
} 
issues on the media news portals, especially in the year before the Parliamentary elections. Even the parliament members who were silent during their term started posting articles in these portals. This situation creates an interest of scholars to analyze the specifics of the communication of politicians before the elections by evaluating a number of specific factors contributing to the election results.

We suggest that the changes within political spectrum in Lithuania might occur due to a number of factors: new party emergence before the elections; parallel referendum campaign; politicians activity in using new communication technologies such as social networks and media news portals for communication with voters.

Emergence of the new political party in Lithuania's context of political development is rather common phenomenon. In 2000, New Union/ Social Liberals emerged before the elections. In the next 2004 elections Labor Party was created. These parties were followed by Tautos prisikelimo partija (Nation Resurrection party) in 2008, and Drasos Kelias (Courage Way) in 2012. In spring 2016, popularity of Union of Greens and Peasants is moving towards its peak. This party is not new but it remained in the margins of politics for a long time having no representatives elected by party lists in the Parliament. This party might be called as new party model in Lithuania because the leader of the party invited to participate nonpartisan personalities with a party lists in the Parliamentary elections. As a rule, these newly emerging parties usually enter the governing majorities. The only question is about their longer perspective. These new formed parties either solidify their presence in the political spectrum (as New Union first, and Labor Party later did, or gradually disappear from it (such as Tautos prisikelimo partija, and, most reliably, Drasos Kelias). All these new parties are gaining popularity not only because they are new but due to their communication related to the interests of the big groups of society.

Parallel referenda campaigns coinciding with regular elections (or just discussions on them) is also becoming a stable feature of Lithuania's political process. In 1996 four referendums, then one in 2008, and one in 2012 were organized together with parliamentary elections. They were initiated and supported by representatives of both parliamentary majority and minority. This year was a wish to initiate referendum on Dual Citizenship during the Parliamentary elections but after the opposition from the World Lithuanians Community this plan was changed. This tendency rises the questions whether is a strive of particular political actors to lower chances of their opponents in the "first order" (in this case - parliamentary) campaigns ("synergy")? Do we treat voting in referendum as a supplement helping to find the convenient topic for the discussion in the elections 
avoiding the other important topics or we really campaigning for the question of referendum, for instance, the single issue referendum vote on atomic energy.

Use of social media in the election campaigns is rather new phenomenon but there is already enough empirical data to draw some conclusions how important this factor is, particularly, in nowadays Lithuania for being elected. The parties aiming to attract attention of younger voters have to be active in communicating using the new media technologies.

This article is aiming at the overview of the contextual factors important for the election results by discussing the specifics and importance of new modern communication tools among the other factors such as emergence of new political actor ("new faces" links with long term "top stories"), and parallel vote on the voting day (such as referendums).

The objects of the analysis are as follows: 2012 Parliamentary elections together with referendum on new nuclear power station; 2016 Parliamentary elections (forthcoming).

The analysis uses data collected by using various methods of collecting the research data: analysis of the publications of internet media news portals (predominantly the popular media news portal delfi.lt and 1.rytas.1t) collected by searching the portal using key-words "Seimo rinkimai 2012" (Seimas election 2012) and "Seimo rinkimai 2016" (Seimas election 2016); Analysis of official Facebook pages of political parties of Lithuania by performing quantitative and qualitative analysis of the messages; Interviews with leaders of political parties by trying to know their opinions about the importance of electronic media and social networks for their political success.

\section{CAMPAIGNING ON THE INTERNET: NEWS MEDIA PORTALS AND SOCIAL NETWORKS}

Elections being a core of democracy are important because they allow us the freedom to participate in selecting our leaders; provide us with the opportunity to determine how our own interests can best be served; provide the legitimacy with which to govern (Trent, 2011, p.3). Every election has two phases - campaigning and voting. Elections campaigns are of great importance by providing information about the candidates and helping to make our choice, facilitating our decision on the voting day. Thus this paper concentrates on political campaign communication aspect in Lithuanian parliamentary elections.

The core of each election campaign is communication. It serves as the bridge between the dreams or hopes of the voter and the actions of the candidate.

"Campaign communication is the means by which the campaign begins, proceeds, 
and concludes" (Trent, 2011, p.17). This paper analyses the usage of new media in campaign communication. The new media and communication technologies are essential elements of contemporary electoral politics. They have impacted the creation, collection and dissemination of information in campaigns. The new media enhances citizen issue understanding and political engagement. Though now we have candidate-centered campaigns, as Bruce Gronbecks (2009, p. 229) argues, we are transitioning to the citizen- centered campaigns offering variety of ways of participations and encouraging more political participation. Online users are active in public conversations and citizens influence the political agenda of politicians through their observations, experiences and concerns expressed over the Internet.

Facebook is a social networking site which is rather new mean of communications in political campaigns. It first entered electoral politics in 2006 with "Election Pulse", a section containing profiles of the candidates running for federal elections in USA (Baumgartner and Morris, 2010). Soon it became popular worldwide, especially after the 2008 American presidential elections and Obama campaign when traditional media was overshadowed by new media technologies and Internet (Hendricks and etc., 2010, p. xi). Facebook is instantaneous, interactive, and personal; allowing making and supporting political image. It allows politicians connections with supporters on a more personal basis, targeting younger voters, to stay connected in a variety of ways throughout a campaign.

Media News portals are gaining popularity in readership among the voters. These communication channels are winning over tradition media like printed newspapers. More and more people argue that they get the political news from a several media news portals. Accordingly political market specialists also consider these portals as important channels of advertising and communication message spread with voters in the political campaigns.

In the following chapters we present and discuss the data from the monitoring of Facebook and media news portals in Lithuania before the two mentioned elections

2 PARLIAMENTARY ELECTIONS OF OCTOBER, 2012, TOGETHER WITH THE REFERENDUM ON THE NEW NUCLEAR POWER PLANT

\subsection{News media portal analysis}

Analysis of the internet media news portal delfi.lt was made retrospectively from the data taken from the search system of this portal on April 10-12, 2016. 
3400 publications were found using the search by key words Seimo rinkimai 2012 with further detailed analysis of 200 of them. For the contrast, search system of the portal lrytas.lt shows only 254 publications.

The publications can be categorized into four groups. First, relatively small part of all the publications was devoted to the formal rules of the elections (5 publications). Here the timetable of elections was published convenient for a voter together with the list of candidates followed by instruction how to vote in the Lithuanian embassy in London. 17 party lists and one coalition of the parties were intended to participate in the elections 2012. (Puryte, 2012).

Second, prognoses of the elections were discussed in the publications (13 publications). Here, parties and their activists are analyzed commonly; then, leaders of the parties; a number of publications are devoted to the particular most important electoral districts (71 one-mandate districts are formed in Lithuanian parliamentary elections besides to one multi-mandate district; see Table 1) in the bigger cities such as Vilnius, Kaunas, and Panevėžys but mainly through a prism of the perspectives of political parties. Part of the publications but relatively small publish and analyze data of public opinion polls. More comments are placed about bigger parties with their winning perspective. Political analysts are among most frequent authors of publications together with journalists writing about different themes (K.Girnius, N. Mačiulis, V. Laučius, V. Gaidys, and others).

Third, a group of publications reviews election process and its peculiarities (20 publications). The overall results are published and overviewed with special stress on the perspectives of political parties to participate in governing coalition building; an important part of publications is based on the interviews with party leaders. More frequently are mentioned parties such as Labour party, Homeland Union (why did they lose their campaign), Polish Electoral Action of Lithuanian Poles, Order and Justice, Artūras Zuokas'TAIP, Social Democrats, and others (ELTA ir lrytas.lt, 2012). As usual, speculations on why younger people avoid participating in the voting are presented. A number of publications concentrate on particular cases of violations of electoral laws (the topic is exploited increasingly compared with previous years in interconnection with annulment of the part of election results). Part of publications discusses the perspective to get particular posts after elections, etc.

Fourth, more generalized analysis of political processes in the context of these particular elections is presented. Despite the small number of this kind of publications partly overlapping with previous categories, there is at least an effort of theorizing. (Mažylis, Jurgelionytė, 2012; Mažylis, Unikaitė-Jakuntavičienė, Ivanovas, 2014). Although particular problems typically are touched in one publication, anyway, it is interesting to mention them. 
The most popular topics and their discussions are as follows:

- Buying votes. They are calculating, one of the known parties was to buy up to 5 thousand votes alone.

- Changing parties immediately prior to the elections by particular well known politicians.

- Passive stance of young voters (several publications).

- Overall low turnout.

- Naïve expectations of voters.

- Unfulfilled promises to emigrants to allow/ simplify their vote.

- "Zero money - zero result". It is about, how much campaign does cost for participants.

- Soviet style thinking of electorate is still prevailing (Špakauskas, 2012).

Table 1: Main political parties of Lithuania (results of the elections, 2012)

\begin{tabular}{|c|c|c|}
\hline Party & $\begin{array}{c}\text { Mandates (party lists } \\
\text { in the multi-mandate } \\
\text { district) }\end{array}$ & Single mandates \\
\hline Social Democrats & 16 & 19 \\
\hline $\begin{array}{c}\text { Homeland Union/ Lithuanian } \\
\text { Christian Democrats }\end{array}$ & 12 & 12 \\
\hline Labor Party & 17 & 5 \\
\hline Order and Justice & 6 & 3 \\
\hline Liberal Union & 7 & 3 \\
\hline Courage Way & 7 & $\ldots$ \\
\hline Polish Electoral Action & 5 & 71 \\
\hline OTHERS & 70 & 23 \\
\hline TOTALLY & & \\
\hline
\end{tabular}

Source: prepared by authors according to Electoral Committee of the Republic of Lithuania, www.vrk.1t/balsavimo-rezultatai

The table 1 shows the final results of the elections. Despite higher activities in the social media of and big attention in media portals to the main ruling party, Homeland Union/ Lithuanian Christian Democrats, the center left parties such as Social Democrats and Labor Party won. 


\subsection{Social network Facebook use in election campaign communication in Lithuania}

Lithuania has been one of the world's leaders in fiber-optic internet spread. The citizen usage of internet is high. Therefore it is clear that the internet role in election campaign depends basically on the will and ability of politician to use it for campaigning. Lithuanian political parties and politicians started to use social networks more actively before the last Parliamentary Elections in 2012. In a four year period personal and party Facebook sections among the Lithuania politicians became very popular and every politician is trying to use it actively, especially if he is trying to reach his younger electorate. So, how active were the politicians in the Facebook during the last elections in Lithuania? What content dominated their profiles? How many reactions their messages or information received?

The interviews made after the 2012 elections with the representatives of major Lithuanian political parties' leaders ( 7 politicians from 5 political parties (Liberals, Conservatives, Labour party, Socialdemocrats, Polish election action) showed, that politicians during these elections had two views on the election communication in the Internet. One group stressed the importance of internet on shaping public discourse, agenda setting and keeping politician's image. The second group was suspicious and argued that internet compliments the other means of communication but is not of great importance and they proffered direct personal live communication and television instead of the Internet ("its costs relatively high but the effect is not very great"-Labour, Polish action representatives, 2013).

However, all the politicians were using Facebook for communication but not equally actively. Many parties used the Facebook just to provide the information from their websites and for spreading of this information. They were not active in participating in discussions with followers or initiating themselves discussions. Individual political candidates were using Facebook and were likely to post their messages, opinions, tried to reply to comments of the followers and keep the relationships with citizens. Personalization prevailed in the Facebook communication (individuals were more active than parties). All the politicians indicated that advertizing and communication on the Internet and Facebook as well was important to the success of their party in elections. Conservatives and Liberals said that support of their parties in big cities and among the young electorate was reached with a help of the Internet (Vareikis, 2013). The informants agreed that Facebook has a lot of potential and they will try to use it more actively in future. 
The results of Facebook analysis during the official one month campaign before the 2012 elections indicated a rather active involvement of parties into communication via Facebook. In total 310 messages were found in the Facebook pages of political parties: Labour party - 36; Courage way (Drasos kelio) party - 14 ; Lithuanian Republic Liberal movement - 49; Lithuanian social democrats party - 82; Party Order and Justice - 1; Homeland Union - Lithuanian Christian Democrats (conservatives) - 128 .

Majority of messages posted in parties Facebook accounts were related to the elections. Analysis indicates that parties tried to share the content which was prepared in advance for the other sources: mainly information from parties' websites, information about the parties from the media news portals prepared by journalists or written by party members was provided. Parties liked posting and sharing of the pictures with party members and videos. $88 \%$ of Social democrats party Facebook news was sharing of news from their website. Homeland union was likely to share information from their website and from special election website as well. Less than 1/5 of information provided in the Facebook sites of all the parties were created especially for Facebook. - Various messages, pictures, events. Majority of such messages were provided by the Liberal Movement.

The parties provided various types of personalized information. Labour party and Courage way provided majority information about their party leaders. More varied representation of leadership was among the Liberals and Homeland Union. They provided information not only about the party leaders but about other party well known politicians, leaders as well. Social democrats had a strategy not to accentuate the leader and they stressed the group leadership, collective leadership by providing information about many politicians. In the personalised messages parties were likely to present personal image of the politician by stressing its personality and opinion on the actual issues.

Political parties were not very active in segmentation of messages. They were more likely to post basic information relevant to all the segments of electorate. More messages with relevant information for a certain group provided three parties - Labour party, Liberal Movement and Lithuanian Social democrats. Majority of these segmented messages were delivered for certain regional groups of electorate and were related to the issues or/and events in the regions (Vilnius, Kaunas, Utena, Trakai). Less than a half of messages were prepared for the people growing children and other groups-young people, workers. 
Chart 1: Personalized messages (\%)

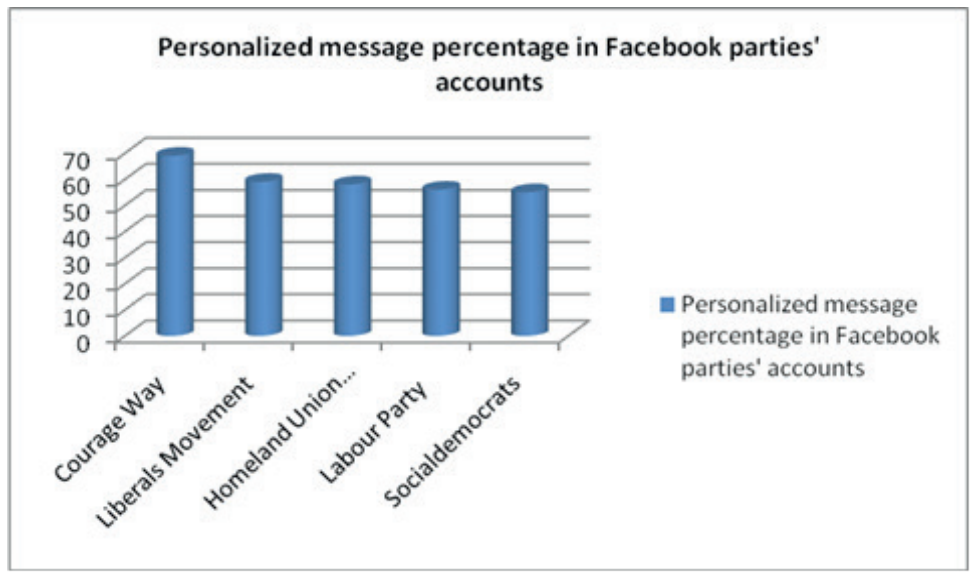

Source: prepared by authors according to the monitoring data

Chart 2: Message segmentation in Facebook

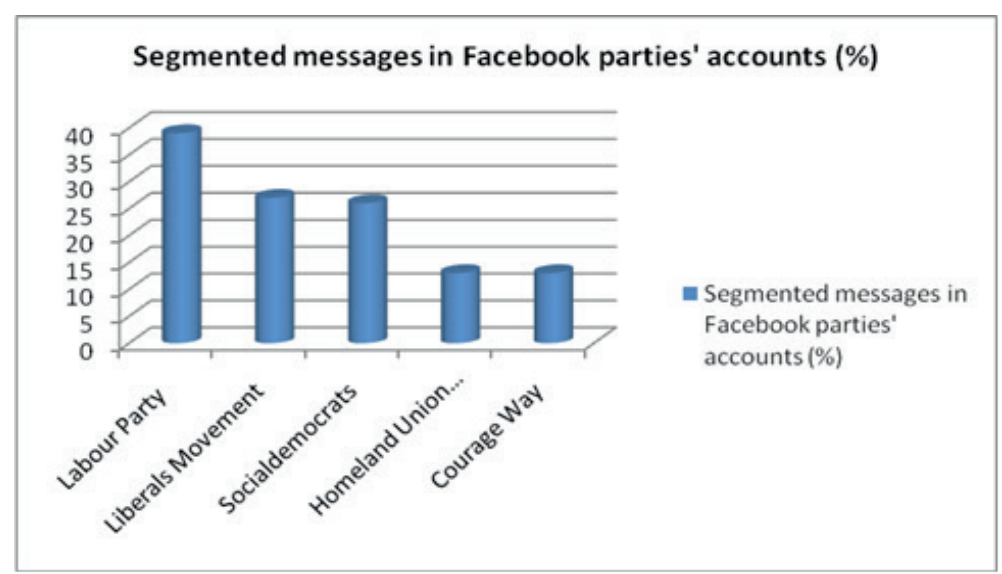

Source: prepared by authors according to the monitoring data

Positive strategies of communication prevailed in Facebook communication. Parties were posting negative message but not very actively. More than other parties provided negative messages Lithuanian Social democrats and Homeland Union (conservatives). They criticized each other's activities (Social democrats criticized the government which had leadership of conservatives, campaigning 
and programme; Conservatives criticized the Vilnius municipality work, opposition parties activities). Liberal movement was the most positive.

Chart 3: Negative news dynamics in Facebook profiles of the parties during election camapign in 2012

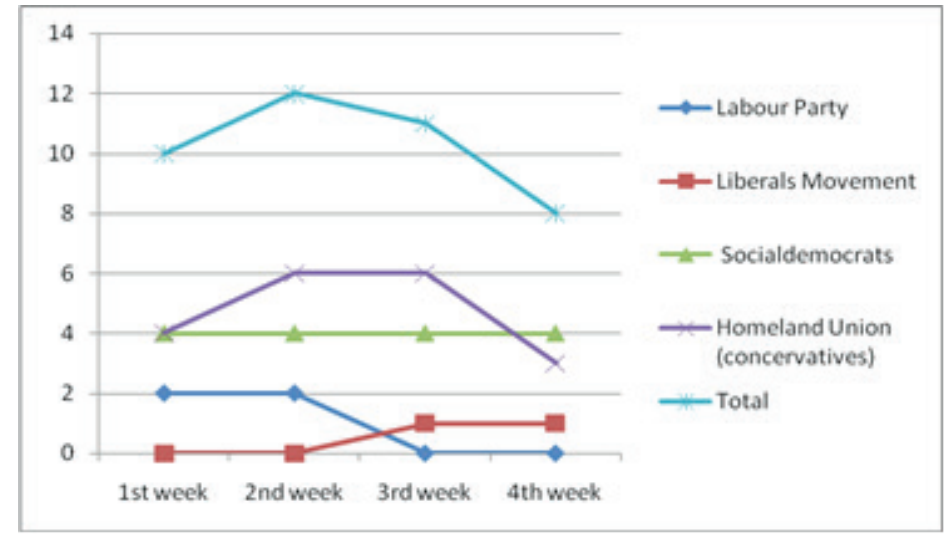

Analysis of interactivity in Facebook reveals that highest interactivity had activities of liberals. About a half of messages were debated among the followers, commented and discussed by party politicians, leaders and readers. Politicians actively invited followers to participate in various events, surveys and support party members.

From the results of Facebook analysis we may see that politicians and political parties during the last elections had an aim to mobilize and inform the voters. They had no intention to change the minds of voters because the majority of activities on Facebook was posting, sharing of information but not discussing or commenting. Parties were not active in replying to the comments.

The analysis of political parties'communication on the Internet in 2012 election shows, that agitation in the internet was not equally popular among the parties. There are 3 groups of them: The first - Liberal Movement and Homeland Union. $1 / 4$ of the campaign budget was delivered by liberals to the campaign agitation on the Internet (Facebook, media news portals, etc.). They considered internet as important mean of communication and shared a lot of information, targeted messages for certain groups, more positive messages and comparatively various and more interactive messages than other parties. Homeland Union actively used Internet: posted a lot of information, delivered $1 / 5$ of budget to the Internet campaigning, shared a lot of negative news, critiques, and its own agitation was more original and more innovative than other parties ${ }^{6}$. The second 
group Lithuanian Social democrats and Labour party. They paid less attention to the Internet communication. The third is Polish Election Action, Courage way and Oder and Justice, which poorly used Internet for elections and provided less information than others.

Comparison of political parties' activities on the Internet and results in the elections shows that more active communication allowed getting more success in elections, with exception of right parties, which agitated more actively but received fewer votes (this was due to the principle of the pendulum positionopposition). They were in a position and were changed by other parties.

\section{LITHUANIAN PARLIAMENTARY ELECTIONS, OCTOBER 2016 (FORTHCOMING)}

\subsection{Media News portals analysis}

The analysis of the media news portal delfi.lt on April 10-12, 2016, by searching publications according to key words Seimo rinkimai 2016 showed 2200 publications related to the elections. Further, 200 publications were analyzed more in detailed; some categorization of publications was made.

First, Official information with the guide for voters (4 publications: when elections will take place, what is forbidden, how to fill in the ballot, and other advices to the voter. This is mainly the information of Electoral Committee but typically popularly adopted by its members or others.

Second, rather sad storytelling what is done/ not done by political parties to win elections commented by political analysts (Ivanovas, 2016).

Third, discussions on electoral reform are presented. In different publications this topic is addressed directly and indirectly. Popular discussion is on liquidating single-mandate districts (arguments in favour and against are presented in the 3 publications). The second topic covered is the idea of introducing electronic vote (2 publications). The introduction of the dual citizenship thus allowing voting for bigger numbers of emigrants is the third one theme. The rest of the topics would be as follows: changing borders of electoral districts and the fear of the politicians that it will infringe existing status quo; precluding possibility to participate public committees in the elections together with political parties (Mažylis, Leščauskaite, 2015); some publications concluding that there will be no these innovations in the forthcoming elections of 2016. (BNS, 2015).

Fourth, publications are depicting pre-election process. This topic overlaps with another, such as prognoses. More than 30 publications discuss different 
aspects of pre-electoral coalitions, positions of parties and particular coalitions, party lists and other important aspects are discussed in rather detailed.

Politicians are popular objects of the discussions in publications. Politicians of today's opposition parties prevail in the publications. Arturas Zuokas, Andrius Kubilius, Algirdas Paleckis, Žygimantas Pavilionis, Aušra Maldeikis, Naglis Puteikis, Guoga, Saulius Skvernelis, Gabrielius Landsbergis (especially two last-mentioned) are mentioned in more than 20 publications. This is not a coincidence. S. Skvernelis decided to refuse the post of Home Affairs Minister in order being able to participate in the elections with gaining the popularity party of Greens and Peasants. G. Lansbergis also refused the post of European Parliament member in order to lead Homeland Union party to the elections. Many commentators discussed their decisions and activities.

Parties gain big attentions as well. More powerful and more challenging parties are mentioned frequently - such as Homeland Union, Labour Party, Order and Justice, Arturas Zuokas' list, Liberals, Social Democrats, and Greens and Peasants. As for organizations, more or less equal attention is paid but when about personalities, attention is far not equal. (See above).

Prognoses (prevailing speculations) are among the most popular topics. Approximately 30 prognoses are presented on who will win elections with almost no comments on what will be then changed in Lithuania's politics. The part of the publications is written by the politicians themselves (Valentinas Mazuronis, Birutè Vèsaite, Ramūnas Karbauskis). Typically, they prognosticate victory for themselves. The political analysts discuss a number of possible perspectives. One version is presented that governing coalition of Social Democrats with Liberals is possible by stressing the diminishing possibilities of other parties (up to 8 publications). Another version includes in the governing coalition Greens and Peasants. Other versions deny these prognoses as uncertain. The attention is paid to the citizen committees, especially in Kaunas: although they are deprived of the passive voting right, however, their support to the party list may be effective. Kaunas example is regarded when talking about diminishing popularity of political parties both on national and on local level; Homeland Union was dominating long time in Kaunas, thus now renewing of this situation is discussed even tiding with renewal of the Kaunas city itself. Here, the changes of electoral districts within Kaunas city territory are discussed, too. (Semaškaite, 2015).

Anyway, the time to the elections is left long, thus chances of no one party can be refused. (Girnius, 2016).

Passiveness of young voters is discussed permanently, partly within context of eventual introducing of electronic vote with overview of strengths and 
weaknesses of this voting mode. (Lèka, 2016).

Some references to the public opinion polls are made but with reservation. iit is popular but not very reliable source for exact prognoses according to the publication author. (Petrauskienè, 2015).

Fifth, some publications discuss eventual inter-relations between elections 2012 and 2016. A number of materials were published in 2014-2015 where different political development aspects are discussed looking for the ties between 2012 and 2016. These comparisons are done in the discussions on who will be in the governing coalition, changes within concrete political parties, speculations on voters' turnout, particular scandals related to the politics (bank collapse, scandal of Labour party), etc. Naturally, analysis of 2012 is more based on facts and expertise when that of 2016 which is more speculative and prognosis based.

\subsection{Social network Facebook use in pre -election campaign communication in Lithuania in 2016}

This 2016 pre-election period political parties are much more active in Facebook communication than four years ago. They not only using the official party accounts on Facebook but encourage their members be active in personal communication and spread of their ideas and messages. The leaders of such political parties as LR Liberals Movement, Homeland Union who are young and modern leaders able to use modern communication tools are trying to post their messages every day. Being in opposition these parties are trying to activate young people and gain governing power in a new governing coalition. New leader of Labour Party who is working in European Parliament is trying to activate the party communication on Facebook as well. We tried to monitor three parties Facebook accounts for a half a year. The activity results of these parties are presented in Table 2.

Table 2: Activity of political parties in Facebook in the period November 2015 - March 2016

\begin{tabular}{|c|c|}
\hline Political parties & $\begin{array}{c}\text { Numbers of political parties } \\
\text { messages in Facebook }\end{array}$ \\
\hline Homeland Union & 71 \\
\hline Lithuanian Republic Liberals Movement & 81 \\
\hline Labour party & 183 \\
\hline
\end{tabular}

Source: prepared by the authors 
The Liberal Movement Facebook account is very popular. It has around 30.000 followers. In their account we may see symbols of the party and election slogan on the cover photo. The party messages are usually accompanied by the pictures and photos. The content of the messages is dominated by critics of the Government, commentaries on the actual daily events and issues, and their suggestions for solving problems or new initiatives. All their messages don not contradict their party values or ideological stances. The Liberals started their campaigning early. That is why they report already about various events related to elections, about their traveling through Lithuania and meetings with various groups of people.

Labour party has fewer followers than Liberal Movement - just around 13.000, but it posted more messages than previous party. Their electorate is concentrated in smaller towns and regions but not in big cities. The party uses this account for connections with party members. The account presents on the cover the slogan of elections "We can what others cannot do" and party symbols. They attempt to be different from the others. Doing the monitoring time Labour party wrote a lot on refugees and immigration issue. They were stressing that nobody shall impose the nation to accept big numbers of asylum seekers. Labour party was not likely to post negative messages on the concurrent activities (just 8 messages). The party also was likely to present its accomplishments during the term in coalition and sometimes even was in disagreement with the partners. What is interesting that they not only post the messages but try to answer the comments.

Homeland Union party Facebook account has about 11.000 followers. They present their symbols as other parties and election slogan "New Homeland Union for the Lithuanian of new opportunities". Their messages are related to the actual problems and special initiatives of the party. For instance, they tried to show that opinion of the people is important by inviting the people to present their ideas for the project "turiuideja.lt" by promising that the most reasonable ideas will be discussed in the parliament. The party differs from the other parties in its critical messages amount. They posted a lot of messages criticizing governing party and Government leader A. Butkevičius. Thus the party is trying to attract attention by negative and humoristic critique which likes young generation of voters. Al the communication in Facebook of Homeland Union is directed towards young and new voters who know new technologies. That is why they use a variety of tools available in Facebook for presenting and spreading of the message. Also the party is contributing to the civic activity by inviting to various important events, commemorations of important events etc.

Analysis of all the parties Facebook pages shows that personalization is important in communication. Al the parties are trying to communicate by 
presenting more messages and photos of their leaders and also famous politicians of the party.

It seems that 2016 elections campaign will be intensive, with many new communication tools used. Facebook will be among the most important tolls of communication and agitation for the parties whose electorate is young and middle - age voters. If they will succeed in attracting their attention and persuasion, they will have great chances be successful in the elections.

\section{CONCLUDING REMARKS}

Four types of specific factors were taken into account when analyzing recent/ forthcoming elections in Lithuania: long term "top stories" leading to the emergency of new party (-ies); parallel vote on the voting day; new campaigning tools; new modes of voting.

Two first factors seem of immediate importance for changes of political landscape: long term exposing new personalities and political parties may be sensitive for election results. Parallel campaign such as of referendum also has direct impact.

New campaigning technologies such as social networks and social media is rather potential factor does not necessarily leading to immediate result but offering the opportunity for the parties to activate and persuade the young and new voters who are not used to look for the information on elections in traditional media. As Facebook analysis indicates, Lithuanian parties understood the importance of this new communication tool and try to be more active in these elections comparing to the last elections in 2012.

Facebook data shows, that this social network contributes to the personalization of political parties and election campaigning and allows the parties to advertise their leaders as well as making more close relationships with their electorate.

\section{REFERENCES}

Boumgartner Jody C. and Jonathan S. Morris. „Who wants to be my friend? Obama, Youth and social Networks in the 2008 Campaign" In Hendricks, Allen John and Robert E. Denton (edt.) Comunicator in Chief: How Barack Obama Used New Media Technology to Win the White House. United Kingdom, Lexington Books, 2010.

BNS. Užkirto kelią Seimo rinkimuose dalyvauti visuomenininkų komitetams. 2015-09-25.

Bruce Gronbeck, „The Web, Campaign 07-08, and Engaged Citizens“ in The 
2008 Presidential Campaign, ed. Robert E. Denton, Jr. . Lanham: Rowman and Littlefield, 2009.

Electoral Committee of the Republic of Lithuania, www.vrk.lt/balsavimorezultatai

ELTA ir lrytas.lt inf. (papildyta premjero komentaru). Referendumas įkvèpé drąsos VAE priešininkams. Energetika, 2012-10-24, 13:28. www.lrytas.lt

ELTA ir lrytas.lt inf. Paskelbtas galutinis „Drąsos kelio“ kandidatų ị Seimo narius sąrašas. Aktualijos, 2012-08-16, 09:41. www.lrytas.lt

Girnius K. Kas laimès Seimo rinkimus? 2016-02-16, www.Delfi.lt

Hendricks, Allen John and Robert E. Denton (edt.) Comunicator in Chief: How Barack Obama Used New Media Technology to Win the White House. United Kingdom, Lexington Books, 2010.

Ivanovas B. Prasideda Seimo rinkimų kampanija. BNS, 2016-04-09

Lèka A. Lietuvą valdo senstanti mažuma. Veidas, 2015-09-23.

lrytas.lt. Politologai: „Jaunimą ị rinkimus atvestų e-balsavimas“. Aktualijos, 2012-09-16, 16:53. www.lrytas.It

Matjošaitytè L. Atsakomybè rinkimų pažeidèjams turi būti griežtesnè. 201601-27, www.Delfi.lt

Mažylis Liudas, Leščauskaitė Vaida. Tiesioginiai merų rinkimai Lietuvoje: užtrukę debatai ir šviežia patirtis. Politikos mokslų almanachas, 2015, No17, p. 38-56. ISSN 2029-0225.

Mažylis L., Unikaitė-Jakuntavičienė I., Ivanovas B. The Rise in Popularity of the Lithuanian Political Party Drasos Kelias. Baltic Journal of Law and Politics. 2014, Volume 6, Issue 1, Pages 63-88, ISSN (Print) 2029-0454, DOI: $10.2478 /$ bjlp-2013-0004.

Mažylis L., Jurgelionyte A. The Lithuanian Referendum on Extending the Working of the Ignalina Nuclear Power Station: The Rationality of Actors Within (Un-)Changing Structures. Baltic Journal of Law and Politics. 2012, Volume 5, Issue 1, Pages 117-136, ISSN (Online) 2029-0454, DOI: 10.2478/v10076-012-0006-y.

Petrauskienė M. Lietuvos laukia permainos. www.delfi.lt, 2015-10-02

Puryte S. VRK patvirtino Seimo rinkimų rezultatus. Aktualijos, 2012-11-04, 20:32. www.lrytas.1t

Semaškaitė E. Rinkejjai nepasitiki politinėmis partijomis. BNS, ELTA, 201503-16. www. Delfi.lt

Trent, S. Judith. Denton, E. Robert. Friedenberg, V. Robert. Political campaign communication: Principles and practices. United States of America: Rowman \& Littlefield press. 2011. 
Špakauskas J. Po rinkimų: Sajūdžio rinkimų parodija. www.Delfi.lt , 201210-24

Vareikis E. Interview done in 2013 in Vilnius. 